Acta Technologica Agriculturae 1

Nitra, Slovaca Universitas Agriculturae Nitriae, 2015, pp. 14-17

\title{
ASSESSING THE EFFECT OF PRESSING MATRIX DIAMETER AND COMPACTING PRESSURE ON DENSITY AND DURABILITY OF PELLETS
}

\author{
Miroslav MACÁK ${ }^{*}$, Ladislav NOZDROVICKÝ1, Juraj MAGA' ${ }^{1}$ Affan Othman HUSSEIN² \\ ${ }^{1}$ Slovak University of Agriculture in Nitra, Slovak Republic \\ ${ }^{2}$ Khabat Agricultural Technical Institute, Erbil, Iraq
}

\begin{abstract}
Pellets made of biomass for energy purposes can be considered as a significant type of biofuel. The efficiency of biopellets depends upon many factors; therefore, in our paper we have focused our attention on measuring the physical properties of biopellets made from lucerne hay and maize stover. The chemical composition of biomass materials is characterised. Biopellets were made on the hydraulic press and their durability was measured on the own instrument designed according to the ASABE S269.4 standard. As the biomass particle size plays an important role in the process of pellets producing, the particle size distribution was determined. According to our experiments, both pressure and diameter had no effect on the durability of pellets for both materials, especially with the pressure force of $100 \mathrm{MPa}$ and $125 \mathrm{MPa}$, whereas with increasing the pressure force to $150 \mathrm{MPa}$ for the die diameter $20 \mathrm{~mm}$ for both lucerne hay and maize stover, a significant increment occurred in the durability of pellets.
\end{abstract}

Keywords: wear resistance, bulk density, die diameter, pressure force, press

Increasing energy demand and decreasing oil reserves make it necessary to find alternative sources of energy. Cellulose materials are attractive as a sustainable source of fuels and chemicals because of their plentiful supply and relatively low cost. World governments and the petrochemical industry alike are looking at biomass as a substitute refinery feedstock for liquid fuels and other bulk chemicals. New large plantations are being established in many countries, mostly in China, but also in North America. Biomass used for energy purposes can have different forms. Due to this fact, biomass is processed in different ways.

Technologies used for biomass processing are producing a very different final product, which leads to very different energy efficiency. Barkóczi et al. (2012) have described a computer simulation model determining the energy efficiency of the incineration of wooden chips. This model based on simulation can be considered as a tool suitable for optimisation of input parameters for the system using wooden chips for energy purposes. Due to this fact, the study of physical properties of the biomass fuel is very important.

Cereal straw is usually considered as a by-product of grain cropping systems and is often used for energy purposes. This material has very specific characteristics that determine the using for energy purposes. Due to low specific density, straw is harvested and baled by straw balers. As mentioned by Žitňák and Korenko (2008), the efficiency of transport bales from a field depends upon the weight of bales package and their shape in Europe and in Russia (Samson et al., 2000; Patzek and Pimentel, 2006).

\section{Material and methods}

In this study, the durability of pellets was measured according to the ASAE S269.4 (2007) standard, the method of which is intended to assess the durability of cubes, pellets and crumbles. A sample of about five pellets was placed in a dust-tight box. The box was rotated around the axis, which was perpendicular to the box and centred in the $300 \mathrm{~mm}$ side. A $230 \mathrm{~mm}$ long baffle was affixed symmetrically and diagonally inside the box of $300 \mathrm{~mm} \times 300 \mathrm{~mm}$. Samples were rotated for $10 \mathrm{~min}$ at 50 r.p.m. During the durability test, five pellets of each treatment were tested with three replications. The durability rating was expressed as the ratio of the original mass of the pellet to the pellet remaining on a $17 \mathrm{~mm}$ opening sieve after tumbling in accordance with the following equation:

Durability $=\frac{\text { mass of pellets or crumbles after tumbling }}{\text { mass of pellets or crumbles before tumbling }} \times 100$

Normally, pellets will be tested immediately after cooling. When the temperature of pellets falls within $-5^{\circ} \mathrm{C}$ of ambient, they are considered cool. If tested at a later time, the time, in hours after cooling, will be indicated as a subscript of durability. If pellets are tested before cooling, there will be a significant weight loss caused by water vaporisation, and apparent durability will be decreased by this loss of water vapour. The loss of water vapour must be determined by making moisture content determinations before and after tumbling and compensating the final mass accordingly.

Contact address: * Miroslav Macák, Slovak University of Agriculture in Nitra, Faculty of Engineering, Department of Machines and Production Systems, Tr. Andreja Hlinku 2, 94976 Nitra, Slovak Republic, e-mail: miroslav.macak@uniag.sk 


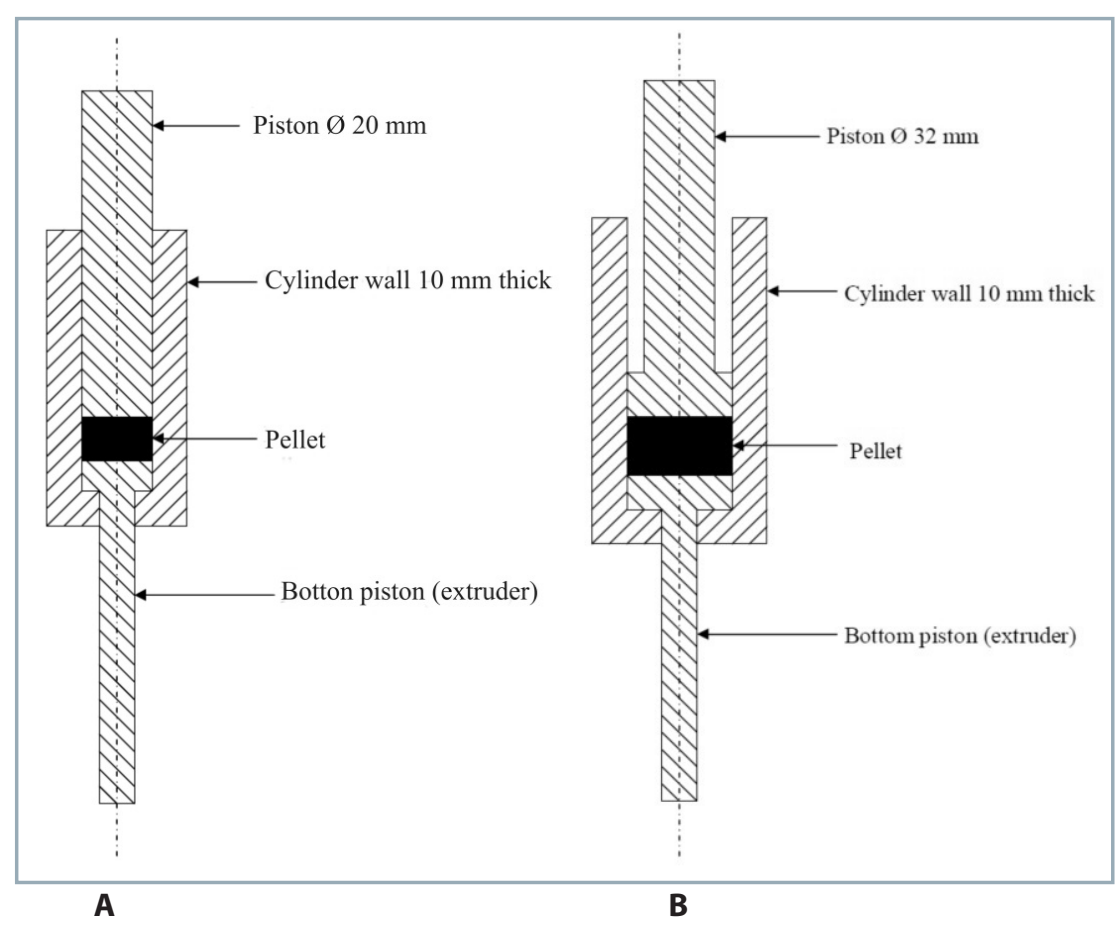

Figure 1 Side section view - cylinder and piston die assembly: (A) $20 \mathrm{~mm}$, (B) $32 \mathrm{~mm}$

When this procedure is followed, durability would be expressed as (95)-1. In this study, all the pellets were tested for durability after two hours from the point of extruding.

\section{Pelleting procedure}

A preliminary experiment was conducted for selecting the proper die diameter and pressure for pelleting the biomass materials. Lucerne hay and maize stover were used for the preliminary study. Two die diameters were used, i.e. $20 \mathrm{~mm}$ (Figure $1 \mathrm{~A}$ ) and $32 \mathrm{~mm}$ (Figure 1B), with three different pressure forces, namely $100 \mathrm{MPa}$, $125 \mathrm{MPa}$ and $150 \mathrm{MPa}$. For the die diameter $20 \mathrm{~mm}$, all pressure forces

Table 1 Chemical composition of biomass materials

\begin{tabular}{|l||c|c|}
\hline \multicolumn{1}{|l||}{ Components in \% DM } & \multicolumn{2}{c|}{ Biomass species } \\
\cline { 2 - 3 } & maize stover & lucerne hay \\
\hline \hline Dry matter & 94.7 & 93.4 \\
\hline Crude protein & 5.3 & 16.75 \\
\hline Crude fibre & 40.81 & 25.56 \\
\hline Carbohydrate & 0.2 & 0.2 \\
\hline Lignin & 6.71 & 6.46 \\
\hline Cellulose & 40.59 & 26.99 \\
\hline Hemi-cellulose & 25.36 & 4.08 \\
\hline Ash & 4.95 & 11.32 \\
\hline
\end{tabular}

feedstock was allowed to flow freely die of $20 \mathrm{~mm}$ and $32 \mathrm{~mm}$, respectively, under room temperature without preheating. The pellets produced were divided into two parts. The first part - their diameter, length and durability was measured immediately after ejection from the die. The second part was stored for three weeks under a room temperature of approximately of $22{ }^{\circ} \mathrm{C}$ and relative humidity of $55 \%$. After storage, also the diameter, length and durability of pellets were measured to determine the impact of storage on the characteristics of pellets. The apparatuses consist of a close fit cylinder and plunger die assembly with a hydraulic press for applying the mechanical pressure required for pelleting.

\section{Results and discussion}

\section{Characteristics of biomass materials}

The results of chemical composition analyses of five biomass materials are given in Table 1. There are variations between the biomass materials in chemical composition; lucerne hay contains the highest amount of protein, while wheat straw contains the lowest, whereas wheat straw contains the highest amount of lignin among the materials and prickly lettuce the lowest. Prickly lettuce has the highest amount of carbohydrate, while the maize stover and lucerne hay have the lowest. Maize stover has the lowest amount of ash, while the prickly lettuce has the highest.

\section{Particle size distribution of biomass grinds} from a funnel and fill the cylindrical

There were big differences among the five biomass materials in terms of the rate of particle size distribution that remained on each sieve opening. These differences in geometric particle size of grinds made from different species are accounted for the difference in their morphology, physical structure and mechanical strength of the material.

Figure 2 shows the distribution of lucerne hay particles on each sieve opening size. The highest rate of chopped particles was $41 \%$ on the sieve with a $2 \mathrm{~mm}$ opening size, whereas the lowest rate was $0.3 \%$ on the sieve with a $5 \mathrm{~mm}$ opening size. The highest accumulation of particles was on the sieves $(3,2$ and 1$) \mathrm{mm}$, reaching $83.6 \%$, whereas the total rate on other five sieves was $16.1 \%$. The geometric mean diameter of the samples was $3.32 \mathrm{~mm}$, which was the finest particle size mean among the other biomass materials. The geometric standard deviation of particles was 1.9. 


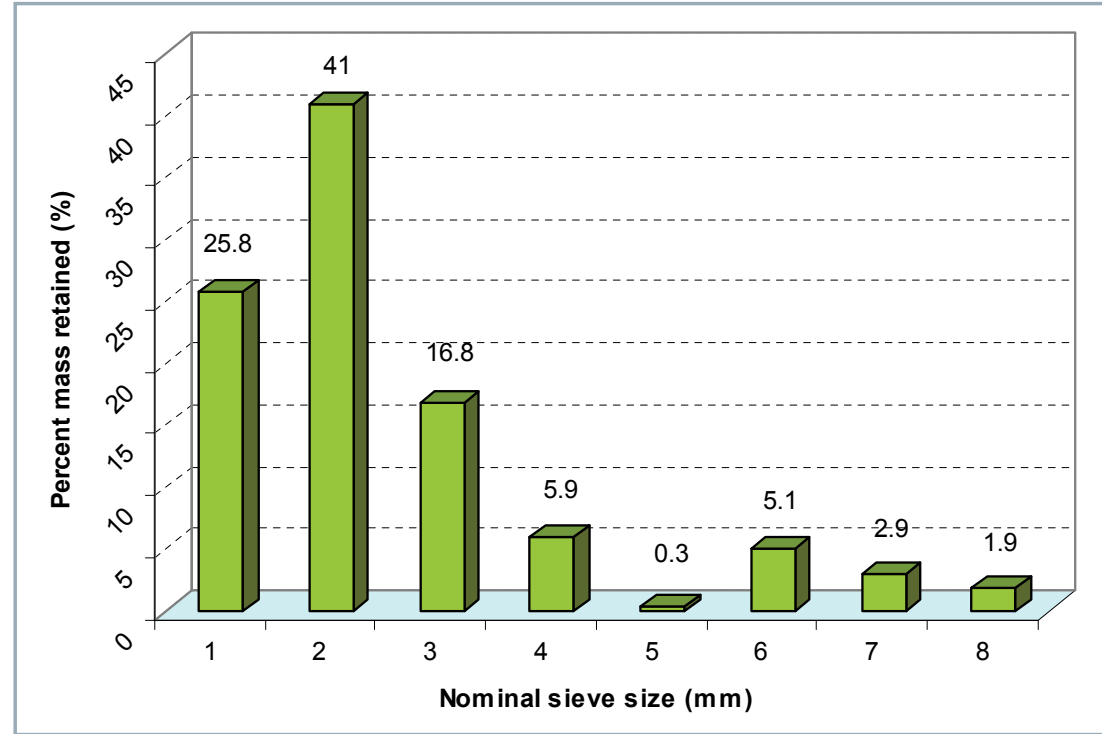

Figure 2 Lucerne hay particle size distribution

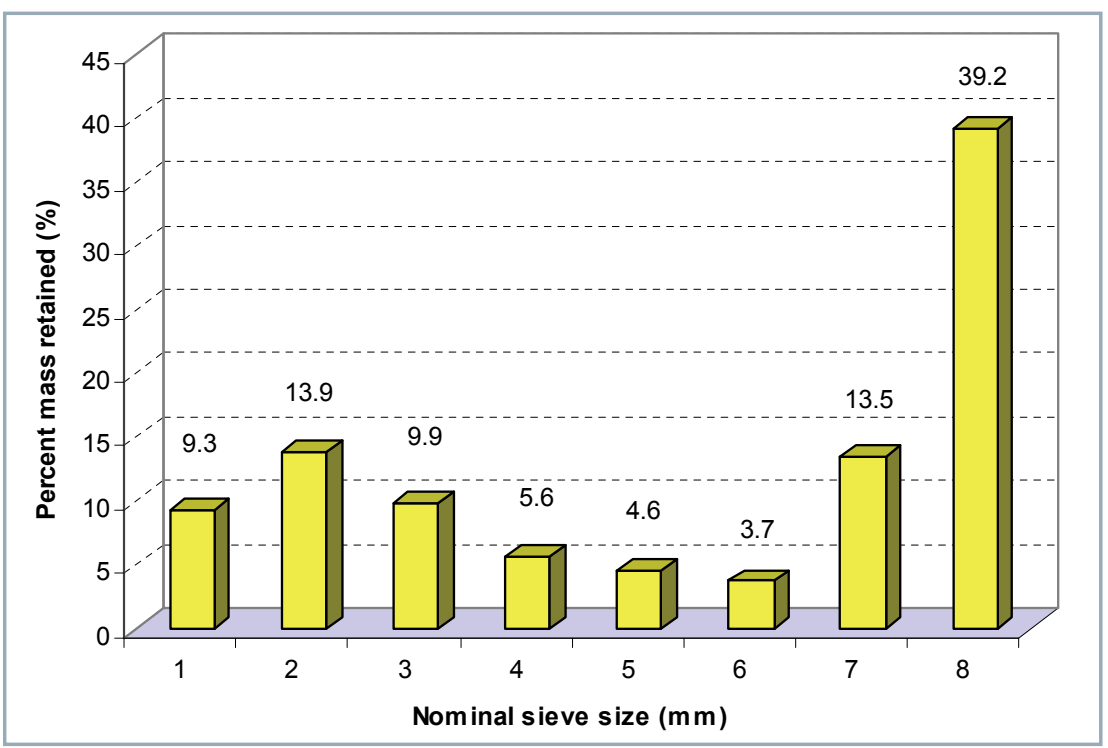

Figure 3 Maize stover particle size distribution

Figure 3 illustrates the distribution of maize stover particles on each sieve opening size; the highest rate of chopped particles was $35.6 \%$ on

the sieve with a $8 \mathrm{~mm}$ opening size, whereas the lowest rate was $3.7 \%$ on the sieve with a $6 \mathrm{~mm}$ opening size. The highest accumulation of particles was on the sieves of $7 \mathrm{~mm}$ and $8 \mathrm{~mm}$. Among all the other materials, maize stover had more than $50 \%$ coarse shape particles. As we mentioned before, it might be due to morphology, mechanical and physical properties. The geometric mean diameter of the samples was $8.5 \mathrm{~mm}$, which was the coarser particle size mean among the other biomass materials. The geometric standard deviation of particles was 2.25 .

The effect of die diameter $20 \mathrm{~mm}$ and $32 \mathrm{~mm}$, pressure force of $100 \mathrm{MPa}$, $125 \mathrm{MPa}$ and $150 \mathrm{MPa}$ and storing on the unit bulk density of pellets produced from lucerne hay and maize stover in the moisture content of $10 \%$ is shown in Table 2. Generally, it can be observed that with increasing the pressure force, bulk density increased for both die diameter pellets. Diameter had a significant effect on the bulk density of pellets. With increasing die diameter, bulk density decreased, and vice versa. Storage has almost a negative effect on the bulk density of pellets for all pressure forces and both diameters, although its effect was slight, especially in case of lucerne pellets made with the diameter $32 \mathrm{~mm}$ and pressure $125 \mathrm{MPa}$.

Table 3 illustrates the effect of three different pressure forces and two die diameters on the mean durability of lucerne hay and maize stover pellets before and after storing, made with the moisture content of $10 \%$. It is obvious that with increasing pressure force, the durability of pellets will increase for both kinds of materials and diameters before storing, but this increment was statistically not significant. Both the pressure and diameter had no effect on the durability of pellets for both materials, especially with the pressure

Table 2 Bulk density of pellets made with different pressure and two diameters with the moisture content of $10 \%$ before and after storing

\begin{tabular}{|c|c|c|c|c|c|c|}
\hline \multirow[t]{3}{*}{$\begin{array}{l}\text { Biomass } \\
\text { materials }\end{array}$} & \multirow{3}{*}{$\begin{array}{l}\text { Bulk density } \\
\text { of chopped } \\
\text { particles } \\
\text { in } \mathbf{k g} \cdot \mathrm{m}^{-3}\end{array}$} & \multirow[t]{3}{*}{$\begin{array}{c}\text { Pressure } \\
\text { in } \mathrm{MPa}\end{array}$} & \multirow{2}{*}{\multicolumn{2}{|c|}{$\begin{array}{l}\text { Unit bulk density of pellets before } \\
\text { storing in } \mathrm{kg} \cdot \mathrm{m}^{-3 *} \\
\text { diameter of pellets in } \mathrm{mm}\end{array}$}} & \multirow{2}{*}{\multicolumn{2}{|c|}{$\begin{array}{l}\text { Unit bulk density of pellets after } \\
\text { storing in } \mathrm{kg} \cdot \mathrm{m}^{-3 *} \\
\text { diameter of pellets in } \mathrm{mm}\end{array}$}} \\
\hline & & & & & & \\
\hline & & & $20 \mathrm{~mm}$ & 32 mm & $20 \mathrm{~mm}$ & 32 mm \\
\hline Lucerne hay & $97.4 \pm 1.4$ & $\begin{array}{l}100 \\
125 \\
150\end{array}$ & $\begin{array}{c}1,186.3 \pm 5.7 \\
1,202 \pm 6.9 \\
1,203.03 \pm 4.9\end{array}$ & $\begin{array}{c}1,023.8 \pm 5.9^{* *} \\
1,077.5 \pm 6.3 \\
\text { NA }\end{array}$ & $\begin{array}{l}1,141.3 \pm 5.2 \\
1,179.2 \pm 5.9 \\
1,183.4 \pm 6.1\end{array}$ & $\begin{array}{c}972.5 \pm 5.6 \\
1,062.2 \pm 5.9 \\
\text { NA }\end{array}$ \\
\hline Maize stover & $57.04 \pm 0.7$ & $\begin{array}{l}100 \\
125 \\
150\end{array}$ & $\begin{array}{c}1,009.4 \pm 4.9 \\
1,031.5 \pm 6.1 \\
1,045 \pm 5.7\end{array}$ & $\begin{array}{c}934.8 \pm 6.3 \\
973.3 \pm 6.2 \\
\text { NA }\end{array}$ & $\begin{array}{c}941.6 \pm 5.9 \\
1,067.6 \pm 6.2 \\
1,005.3 \pm 4.8\end{array}$ & $\begin{array}{c}889.6 \pm 6.1 \\
939 \pm 5.9 \\
\text { NA }\end{array}$ \\
\hline
\end{tabular}

${ }^{*}$ mean \pm standard deviation $(n=5)$; NA - data not available; ${ }^{* *}$ mean difference is significant at $\alpha=0.01$ 
Table 3 Durability of pellets before and after storing in the moisture content of $10 \%$, made with different pressure forces and die diameters

\begin{tabular}{|l||c|c|c|c|c|}
\hline \multirow{2}{*}{$\begin{array}{l}\text { Biomass } \\
\text { materials }\end{array}$} & Pressure in MPa & \multicolumn{2}{|c|}{ Durability of pellets before storing in \%* } & \multicolumn{2}{c|}{ Durability of pellets after storing in \%* } \\
\cline { 3 - 6 } & & \multicolumn{2}{|c|}{ diameter of pellets in $\mathbf{~ m m}$} & \multicolumn{2}{|c|}{ diameter of pellets in $\mathbf{m m}$} \\
\cline { 3 - 6 } & & $\mathbf{2 0} \mathbf{~ m m}$ & $\mathbf{3 2} \mathbf{~ m m}$ & $\mathbf{2 0} \mathbf{~ m m}$ & $\mathbf{3 2} \mathbf{~ m m}$ \\
\hline \hline \multirow{3}{*}{ Lucerne hay } & 100 & $60 \pm 1.9$ & $48 \pm 1.7$ & $63 \pm 2.1$ & $41 \pm 1.9$ \\
& 125 & $66 \pm 1.7$ & $56 \pm 1.2$ & $69 \pm 1.4$ & $68 \pm 1.9$ \\
\hline \multirow{3}{*}{ Maize stover } & 150 & $75 \pm 1.6^{*}$ & $\mathrm{NA}$ & $73 \pm 1.9$ & NA \\
& 100 & $65 \pm 1.9$ & $62 \pm 1.9$ & $74 \pm 2.1$ & $73 \pm 1.2$ \\
& 125 & $70 \pm 2.2$ & $73 \pm 1.9$ & $78 \pm 1.8^{*}$ & $\mathrm{NA}$ \\
\hline
\end{tabular}

* mean difference is significant at $\alpha=0.01$

force of $100 \mathrm{MPa}$ and $125 \mathrm{MPa}$, whereas with increasing the pressure force to $150 \mathrm{MPa}$ for the die diameter $20 \mathrm{~mm}$ for both lucerne hay and maize stover, a significant increment occurred in the durability of pellets, being $(60 \%, 66 \%$ and $75 \%)$ and $(65 \%, 70 \%$ and $82 \%)$ for the pressure force of $100 \mathrm{MPa}, 125 \mathrm{MPa}$ and $150 \mathrm{MPa}$, respectively.

The effect of storage on durability was also investigated (it is shown in the table). Durability fluctuated between increasing and decreasing. In case of lucerne hay pellets made with the $20 \mathrm{~mm}$ diameter and pressure force of $100 \mathrm{MPa}$ and $125 \mathrm{MPa}$, the durability of pellets increased form $60 \%$ and $66 \%$ to $63 \%$ and $69 \%$, respectively, while in the $32 \mathrm{~mm}$ diameter and $100 \mathrm{MPa}$ pressure force, durability decreased from $48 \%$ to $41 \%$, but it increased from $56 \%$ to $68 \%$ when pressure force increased to $125 \mathrm{MPa}$. These results agree with Kaliyan (2008), Franke and Rey (2006), and Saptoadi (2006).

\section{Conclusion}

From the results of this study, we can draw the following conclusions.

The effect of die diameter on the unit bulk density of pellets made without preheating in the moisture content of $10 \%$ : by increasing the die diameter from $20 \mathrm{~mm}$ to $32 \mathrm{~mm}$, the unit bulk density of pellets made from lucerne hay and maize stover decreased.

Lucerne hay and maize stover pellets recorded higher unit bulk density by increasing the pressure force from $100 \mathrm{MPa}$ to $150 \mathrm{MPa}$.

The durability of pellets made from lucerne hay and maize stover increased with increasing the compression pressure from $100 \mathrm{MPa}$ to $150 \mathrm{MPa}$, pellets were made without preheating with the moisture content of $10 \%$.

According to the results, we can suggest the following recommendation for future work: comparing more diameters for producing pellets and observing the effect of each one on the durability of produced pellets. Testing different pressure forces, we can decide on the best procedure for each type of biomass feedstock.

\section{Acknowledgements}

The research leading to the results presented in the paper has received funding from the European Community under the project no. 26220220180: Building the Research Centre 'AgroBioTech'.

\section{References}

ASAE Standard S269.4. 2001. Cubes, pellets, and crumbles definitions and methods for determining density, durability, and moisture content. St. Joseph, Michigan : ASABE.

BARKÓCZI, J. - NOZDROVICKÝ, L. - MACÁK, M. 2012. Využitie informačných technológií $v$ procese realizácie systému technologických zariadení pre spracovanie biomasy na energetické účely. Nitra : SPU. ISBN 978-80-552-0874-9.

FRANKE, M. - REY, A. 2006. Pelleting quality. World Grain May 2006, pp. 78-79.

KALIYAN, N. 2008. Densification of biomass. [PhD Thesis]. USA : University of Minnesota.

PATZEK, T. W. - PIMENTEL, D. 2006.Thermodynamics of energy production from biomass. Retrieved from: http:// books.google.sk/books?id=ThUISXWq0kEC\&printsec $=$

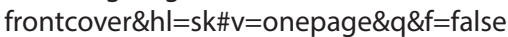

SAMSON, R. - DUXBURY, P. - DRISDELLE, M. - LAPOINTE, C. 2000. Assessment of pelletized biofuels. Retrieved from: http://www. reap-canada.com/online_library/Reports\%20and\%20Newsletters/ Bioenergy /15\%20Assessment\%20of.PDF

SAPTOADI, H. 2006. The best biobriquette dimension and its particle size. In Proceedings of the $2^{\text {nd }}$ Joint International Conference on ,Sustainable Energy and Environment (SEE 2006)'. Bangkok, Thailand. [Retrieved 2013-04-12]. Retrieved from: http:// www.jgsee.kmutt.ac.th/see1/cd/file/C-004.pdf

ŽITŇÁK, M. - KORENKO, M. 2008. Výkonnost' a energetická náročnost' dopravných prostriedkov pri zbere a doprave balíkov slamy. Nitra : SPU, 2008. pp. 181-185. 